\title{
Durophagous Mosasauridae (Squamata) from the Upper Cretaceous phosphates of Morocco, with description of a new species of Globidens
}

\author{
N. Bardet ${ }^{1, *}$, X. Pereda Suberbiola ${ }^{2}$, M. Iarochène ${ }^{3}$, M. Amalik ${ }^{4} \&$ B. Bouya ${ }^{5}$ \\ 1 UMR 5143 du CNRS, Département Histoire de la Terre, Muséum national d'Histoire naturelle, 8 rue Buffon, 75005 Paris, France. \\ 2 Universidad del País Vasco/Euskal Herriko Unibertsitatea, Facultad de Ciencia y Tecnología, Departamento de Estratigrafía y Paleontología, \\ Apartado 644, 48080 Bilbao, Spain. \\ 3 Ministère de l'Energie et des Mines, Direction de la Géologie, BP 6208, Rabat, Morocco. \\ 4 Office Chérifien des Phosphates, Centre Minier de Ben Guerir, Morocco. \\ 5 Office Chérifien des Phosphates, Centre Minier de Khouribga, Morocco. \\ * Corresponding author. Email: bardet@mnhn.fr
}

Manuscript received: November 2004; accepted: January 2005

\begin{abstract}
Three durophagous mosasaur species are represented by isolated teeth in the Upper Cretaceous (Maastrichtian) phosphatic beds of Morocco. Globidens phosphaticus nov. sp. is characterised mainly by a strong heterodonty, with mid-posterior teeth being bulbous, irregularly oval in crosssection, and having an inflated posterior surface, a large eccentric located and recurved apical nubbin, vertical sulci on medial and lateral faces, no carinae and an enamel surface covered by anastomosing ridges. Teeth of Prognathodon currii are broad and tall, straight cones, slightly swollen at the base, and with two serrated carinae. These two taxa have been collected from all the phosphatic series (lower to upper Maastrichtian) in the Ganntour Basin (Morocco). Globidens phosphaticus nov. sp. is probably also represented at other Maastrichtian phosphatic sites along the southern margin of the Mediterranean Tethys. Prognathodon currii was previously known only from the Upper Cretaceous phosphates of Negev. of the third taxon, Carinodens belgicus, only a single tooth (now lost) is known from the Oulad Abdoun Basin (Morocco); this is low, swollen, laterally compressed and bicarinate with a large apical nubbin. Previous records of this species include Europe and Brazil.
\end{abstract}

Keywords: Mosasauridae, Globidensini, Globidens phosphaticus nov. sp., Prognathodon, Carinodens, Maastrichtian, phosphates, Morocco

\section{Introduction}

Active collaboration between the Office Chérifien des Phosphates (OCP, Casablanca, Morocco), the Ministère de l'Energie et des Mines (Rabat, Morocco) and the Centre National de la Recherche Scientifique (CNRS, France) has resulted in new palaeontological field campaigns during recent years in the Upper CretaceousPaleogene phosphatic basins of Morocco. Collected here is an abundance of vertebrate remains, including mosasaurids, plesiosaurs, chelonians and, less commonly, pterosaurs and dinosaurs from strata of Maastrichtian age (Bardet et al., 2004a, b, 2005; Pereda Suberbiola et al., 2003, 2004), as well as new taxa of actinopterygians, crocodilians, chelonians, mammals and birds from Paleogene beds (Cavin et al., 2000; Gheerbrant et al., 2003 and references therein; Hua \& Jouve, 2004; Jouve, 2004; Bourdon et al., 2005; Jouve et al., 2005). The new discoveries significantly improve our knowledge of these vertebrate assemblages, previously either unknown or represented by fragmentary or isolated remains only (Arambourg, 1952).

Mosasaurid remains are very abundant and diverse in the uppermost Cretaceous phosphates of Morocco, and species of Halisaurus, Mosasaurus, 'Platecarpus', Prognathodon, Globidens and Carinodens (Bardet et al., 2004a, b, 2005) have been 
recognised. The aim of the present paper is to describe durophagous taxa, inclusive of a new species of Globidens, on the basis of a large and representative sample of isolated teeth.

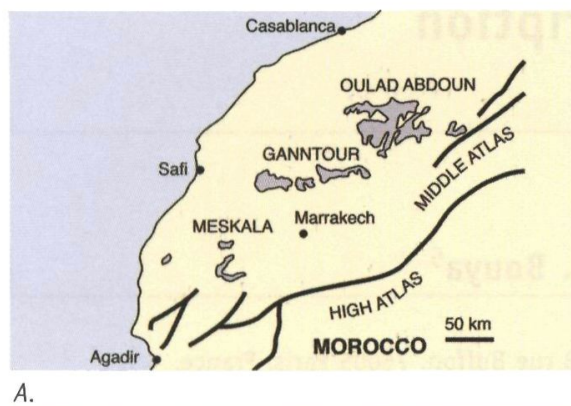

A.

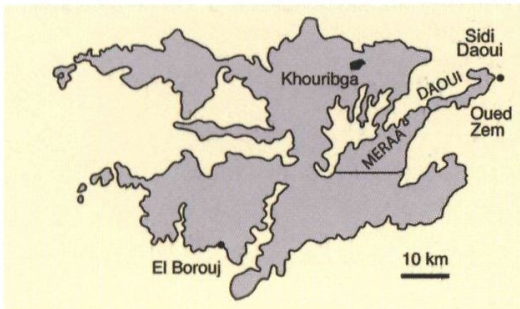

$B$.

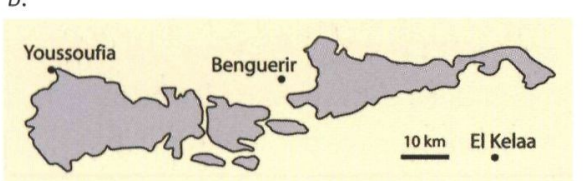

C.

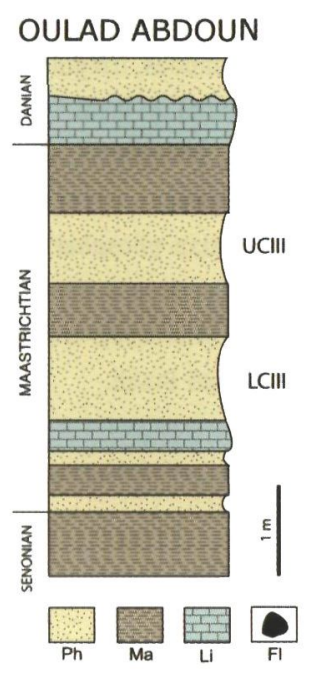

D.

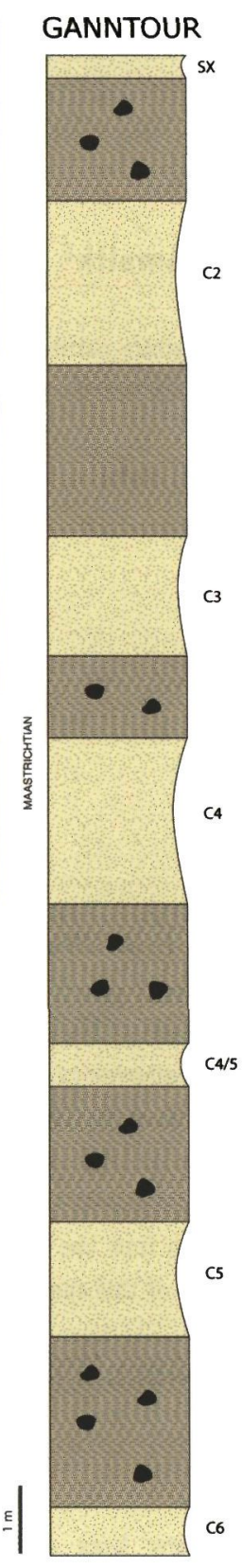

E.

Fig. 1. A. Map showing the location of the main phosphatic basins of Morocco; B. details of the Oulad Abdoun Basin with the location of the phosphate zones currently exploited (Daoui, Meraa); C. details of the Ganntour Basin with the location of phosphate zones currently exploited (Ben Guerir, Youssoufia); D. schematic stratigraphical log of the Maastrichtian phosphatic series in the Oulad Abdoun Basin near Oued Zem; E. schematic stratigraphical log of the Maastrichtian phosphatic series in the Ganntour Basin near Ben Guerir. Abbreviations: Fl: flints; Li: limestones; Ma: marls; Ph: phosphates.

\section{Geographical and stratigraphical occurrences}

During the Late Cretaceous and Early Paleogene, platforms bordering the southern Tethys were characterised by phosphatic sedimentation in warm and shallow-marine environments (Lucas \& Prévôt-Lucas, 1996). Phosphatic deposits currently crop out from North Africa to the Middle East where they are an economically valuable resource.

The phosphatic deposits of Morocco, known since 1908, have been exploited since the 1920s (Office Chérifien des Phosphates, 1989), and form part of the Mediterranean Tethyan phosphogenic province (Lucas \& Prévôt-Lucas, 1996). Outcrops are situated in several basins, from northeast to southwest: Oulad Abdoun, Ganntour, Meskala, Souss and Bu-Craa in the Sahara (Fig. 1A). Stratigraphically, these phosphatic strata range from uppermost Cretaceous (Maastrichtian) to the midEocene (Lutetian), spanning the longest time interval of all Tethyan phosphates (Lucas \& Prévôt-Lucas, 1996).

The Maastrichtian phosphatic series in the Oulad Abdoun Basin near Khouribga (Couche III or level CIII) is very condensed, being only about 2 - $5 \mathrm{~m}$ thick (Fig. 1B, D). It consists of a basal grey limestone and yellow, soft phosphates (lower CIII) as well as grey, soft phosphates with brown streaks and marls (upper CIII). The series is late (but not latest) Maastrichtian in age (Cappetta, 1987).

The Maastrichtian phosphatic series in the Ganntour Basin (Ben Guerir area; Couche 6 to Couche 2 or levels $\mathrm{C} 6$ to $\mathrm{C} 2$, and Sillon $X$ ) is not condensed and is better developed than that in the northeasterly part of the Oulad Abdoun Basin; it may reach about $45 \mathrm{~m}$ in thickness (Fig. $1 \mathrm{C}, \mathrm{E}$ ). The soft phosphatic beds are separated by barren calcareous and marly levels. 0n selachian evidence (H. Cappetta, pers. comm.), this series ranges from earliest to latest Maastrichtian in age.

From a palaeogeographical point of view, the phosphates of the Oulad Abdoun and Ganntour basins were deposited in a long and narrow gulf which opened to the Atlantic Ocean (Herbig, 1986; Salvan, 1986). The condensed series in the northeasterly part of the Oulad Abdoun Basin probably was deposited in a high-energy, nearshore environment located close to the Palaeozoic Massif Central. The more complete sequences in the southwesterly Oulad Abdoun Basin and in the Ganntour Basin may have been laid down in a deeper, open-sea setting (Office Chérifien des Phosphates, 1989; Lucas \& Prévôt-Lucas, 1996).

\section{Material and methods}

Although they generally have received scant attention, mosasaurid teeth are often characteristic at the generic and even specific levels (Russell, 1967; Lindgren \& Siverson, 2002). In fact, some taxa have been defined mainly on dental features, e.g. durophagous taxa such as Carinodens (Russell, 1967; LinghamSoliar, 1999) and Igdamanosaurus (Lingham-Soliar, 1991). 
The methodology applied here to mosasaurid teeth both in systematic attribution and in reconstructions of tooth rows is more or less comparable to that used for selachian teeth (see Cappetta, 1987). Mosasaur species can be diagnosed on the basis of isolated teeth, provided that a large sample is available, which enables an appreciation of differences due to ontogeny, heterodonty and intraspecific variation, that the diagnosis is accompanied by high-quality illustrations, and that the type series comes from a narrow stratigraphical interval (Lindgren \& Siverson, 2002).

Mosasaurid taxa described here are based on isolated teeth as well and all the criteria above mentioned applied. All but one specimen come from a large sample collected from levels C6 to $\mathrm{C} 2$ in the Ben Guerir area (Ganntour Basin). About 1,850 isolated teeth have been collected, three percent of which are assigned to two durophagous taxa (Globidens phosphaticus nov. sp. and Prognathodon currii).

The Globidens sample comprises about 50 isolated teeth, from different levels within the Ben Guerir series and thus stemming from several individuals. The sample of Prognathodon currii consists of seven teeth also from different levels in the Ben Guerir series; the most characteristic teeth come from level $\mathrm{C} 5$. The single tooth here referred to Carinodens belgicus comes from near El Borouj (Oulad Abdoun Basin) (Arambourg, 1952); of this species no additional material is known to date.

\section{Systematic palaeontology}

Abbreviations - To denote the repositories of material described below, the following abbreviations are used in the text: FMNH Field Museum of Natural History, Chicago, USA; IRScNB - Institut royal des Sciences naturelles de Belgique, Bruxelles, Belgique; MNHN - Muséum national d'Histoire naturelle, Paris, France; OCP - Office Chérifien des Phosphates, Khouribga, Morocco; USNM - United States National Museum, Washington, USA.
Squamata Oppel, 1811

Mosasauridae Gervais, 1853

Mosasaurinae Gervais, 1853

Globidensini Russell, 1967

\section{Globidens Gilmore, 1912}

Type species - Globidens alabamaensis Gilmore, 1912, Selma Chalk (Campanian), Alabama.

Distribution - Of this genus, two species from the Campanian of North America (Alabama, South Dakota, Mississippi, Texas, Arkansas, Kansas) and Europe (southern Belgium) (Russell, 1975; Lingham-Soliar, 1999) are known. The new species from Morocco described here is probably also represented in Maastrichtian phosphatic levels elsewhere in Africa, the Middle East and Brazil (see discussion below).

Globidens phosphaticus Bardet \& Pereda Suberbiola, nov. sp.

Etymology - In reference to the deposits which have yielded this species.

Type series - Holotype (Fig. 2K) is OCP.DEK/GE 337, a mid-posterior tooth; paratypes are OCP.DEK/GE 338, an anterior tooth and OCP.DEK/GE 339-343, all median teeth (Fig. 2A, E-H, J).

Type locality and horizon - Ben Guerir area (Ganntour Basin, Morocco); phosphatic deposits, level C3, Upper Maastrichtian (Cappetta, 1987).

Referred material and distribution - 0nly specimens illustrated have been numbered. OCP.DEK/GE 344-345 represent anterior teeth from level C4 (Fig. 2B, C); OCP.DEK/GE 346 is a median tooth from level C4 (Fig. 2I); OCP.DEK/GE 347, a posterior tooth from level C6 (Fig. 2L); OCP.DEK/GE 348, a posterior
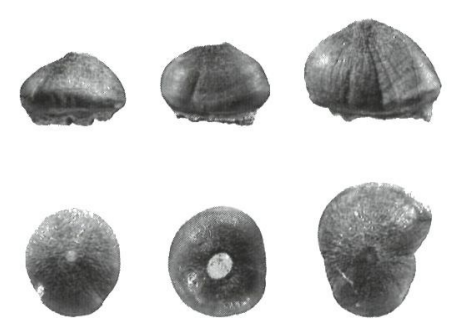

M

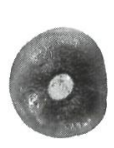

L

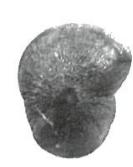

K
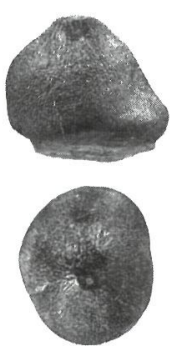

J
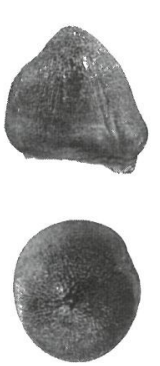

I

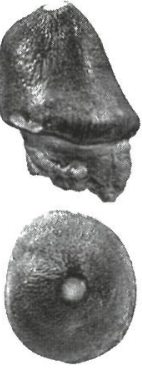

H
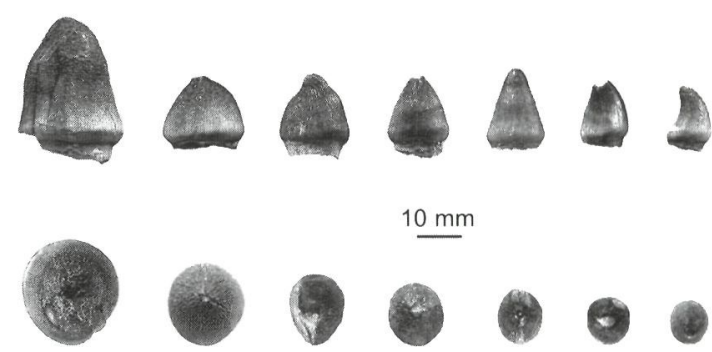

G

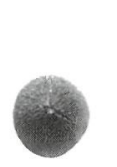

F

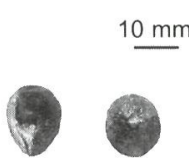

E

Fig. 2. Globidens phosphaticus nov. sp., Maastrichtian phosphatic series of Ben Guerir area (Ganntour Basin, Morocco). Hypothetical reconstruction of the tooth row. Each tooth is figured in lateral or medial view (upper) and occlusal view (lower); A - OCP.DEK/GE 338, paratype, level C3, anteriormost tooth; $B$ - OCP.DEK/GE 344, referred specimen, level C4, anteriormost tooth; C - OCP.DEK/GE 345, referred specimen, level C4, anterior tooth; D. MNHN Arambourg Collection (MNHN PMC-17), referred specimen, phosphatic series, anterior tooth; E-OCP.DEK/GE 339, paratype, level C3, anteromedian tooth; $F$ - OCP.DEK/GE 340, paratype, level C3, anteromedian tooth; G - OCP.DEK/GE 341, paratype, level C3, median tooth; H - OCP.DEK/GE 342, paratype, level C3, median tooth; $I$ - OCP.DEK/GE 346, referred specimen, level C4, median tooth; J. OCP.DEK/GE 343, paratype, level C3, mid-posterior tooth; K - OCP.DEK/GE 337, holotype, level C3, mid-posterior tooth; L - OCP.DEK/GE 347, referred specimen, level C6, posterior tooth; M-OCP.DEK/GE 348, referred specimen, level C2, posterior tooth. 
tooth from level C2 (Fig. 2M); and MNHN PMC-17, an anterior tooth from an unknown level (Fig. 2D); plus OCP.DEK/GE uncatalogued, forty teeth (six from level C6, 12 from C4, 21 from C3 and 1 from C2); Ben Guerir area (Ganntour Basin, Morocco); phosphatic deposits, lower - upper Maastrichtian (Cappetta, 1987).

This species has previously been recorded from Moroccan phosphates as Globidens aegyptiacus Zdansky, 1935 by Arambourg (1952). G. aegyptiacus has been referred recently to Igdamanosaurus aegyptiacus (Lingham-Soliar, 1991; see below); it differs from the material from Morocco here described. On the basis of the newly collected material, it is now known to occur at all Maastrichtian levels ( 66 to $\mathrm{C} 2$ ) in the Ganntour Basin, but so far there is no record from the upper CIII level in the Oulad Abdoun Basin. Globidens phosphaticus nov. sp. is probably also represented in the Maastrichtian phosphates of Syria, Negev, Jordan, Egypt, Angola and Brazil (see below).

Diagnosis - In comparison to G. alabamaensis and G. dakotensis strongly heterodont. Anterior teeth broadly conical, taller than long, posteriorly recurved then straight, with discrete apical carinae. Mid-posterior teeth bulbous, anteriorly taller than long becoming longer than tall posteriorly, irregularly oval in cross-section, with an inflated posterior surface, a large eccentric and recurved apical nubbin, vertical sulci on medial and lateral faces, no carinae, and enamel surface covered by crude anastomosing ridges.

Description and interpretation - Generally, tooth crowns are robust and low (height never exceeding 1.5 times mesiodistal length), bulbous, swollen above the base, with a large eccentric and recurved apical nubbin, especially well developed on midposterior teeth. The enamel is thick (around $0.5 \mathrm{~mm}$, but can reach almost $1 \mathrm{~mm}$ in largest teeth) and bears crude anastomosing ridges, more pronounced near the apex and on median teeth.

The large sample allows to differentiate six morphotypes, some of which correspond to those defined by Russell (1975). For convenience and to avoid confusion with Russell's terminology, they are here referred to as morphotypes A to F. Similarities to Russell's (1975) morphotypes are outlined. The respective position of each morphotype has been deduced from the observation of mosasaurid general pattern of dental series arrangement and the comparison with a Globidens sp. dentary from the Campanian of Kansas (FHSM VP-13828; courtesy of M. Everhart). Anterior and posterior surfaces of the teeth are determined by the posterior curvature of the apex or apical nubbin of the crown. It has not been possible to determine the labial and lingual surfaces of the teeth neither if the teeth belong to the upper or lower jaw and to the right or left ramus.

Teeth of morphotype A (OCP.DEK/GE 338, 344) are broad cones, posteriorly recurved, taller than long (height may reach
1.5 times mesiodistal length), with a basal circular crosssection (Fig. 2A, B). Faint carinae are present on the apical portion of the crown, and an apical nubbin is missing. Anastomosing ridges occur mainly on the upper part of the crown. Because they are posteriorly recurved, these teeth are interpreted as the most anterior of the dental tooth row.

Morphotype B (OCP.DEK/GE 345, MNHN PMC-17) are broad and straight cones, taller than long (height may reach 1.5 times mesiodistal length), with a subcircular to oval crosssection (Fig. 2C, D). They bear discrete apical carinae and a nubbin. Anastomosing ridges occur mainly on the upper part of the crown. These teeth are interpreted as anterior, located posterior to those of morphotype A and they probably correspond to Russell's (1975) 'type 3'.

Teeth of morphotype C (OCP.DEK/GE 339, 340) are bulbous and have a large, posteriorly recurved, apical nubbin; the height approximately equals the mesiodistal length (Fig. 2E, F). They are subcircular in cross-section. In lateral profile, both anterior and posterior surfaces are convex, and lack carinae and vertical sulci. Anastomosing ridges occur mainly on the apical region. These teeth are considered to have been anteromedian in position.

Morphotype D (OCP.DEK/GE 341, 342) is large, bulbous, taller than long, with a large, posteriorly recurved, and eccentric apical nubbin (Fig. 2G, H). The teeth are shaped irregularly in lateral profile, with a straight to slightly convex anterior surface and an inflated, convex posterior one. The crosssection is subcircular, and lateral and medial surfaces bear one or two vertical sulci, but lack carinae. The enamel is thick (it can reach $1 \mathrm{~mm}$ in largest teeth), with large anastomosing ridges expanded on the surface of the crown, with the exception of its base. These teeth are probably median ones, located posterior to those of morphotype C, and possibly correspond to Russell's 'type 2' (1975).

Teeth of morphotype E (OCP.DEK/GE 346, 343) are the largest, being bulbous and bearing a large, posteriorly recurved and eccentric apical nubbin (Fig. 2I, J). Height equals length, or length slightly exceeds height. They are characterised by an irregular shape in lateral and occlusal profiles. In lateral view, the anterior surface of the crown is slightly convex to slightly concave, with a swollen basal part, whereas the posterior surface is strongly inflated at about mid-height. In occlusal view, the cross-section of the crown is irregularly oval. The lateral and medial surfaces bear one or two vertical sulci, but lack carinae. As in morphotype D, the enamel is thick, with large anastomosing ridges expanded on the surface of the crown, except for its base. These teeth were probably located in the mid-posterior part of the jaw, posterior to those of morphotype D, and may represent Russell's 'type 2' (1975).

Type F (OCP.DEK/GE 337, 347, 348) teeth are bulbous and bear a large, posteriorly recurved and eccentric apical nubbin (Fig. $2 \mathrm{~K}-\mathrm{M}$ ). They are very low, mesiodistal length almost twice the height, and have an irregularly oval cross-section, with 
the anterior surface larger than the posterior one. In lateral view, the anterior surface is convex and the posterior strongly inflated. They lack carinae. The lateral and medial surfaces bear vertical sulci that are generally more clearly marked than in morphotypes D and E. The functional significance of these sulci is unknown. The enamel is thick only on the upper half of the crown. These teeth are considered mid-posterior and posterior, and probably correspond to Russell's 'type 5' (1975).

Comparisons - Assignment of these teeth to the genus Globidens is beyond doubt on account of their having low and bulbous crowns with a strongly swollen base and a wrinkled enamel surface (Russell, 1975; DeBraga \& Carroll, 1993; LinghamSoliar, 1999).

We here refer to Globidens phosphaticus nov. sp. teeth matching the various morphotypes described above and recorded from Maastrichtian phosphates of Syria (Bardet et al., 2000), Jordan (Avnimelech, 1949; Arambourg et al., 1959; Mustafa \& Zalmout, 2001; Bardet \& Pereda Suberbiola, 2002), Negev (Raab, 1963), Egypt (Leonardi \& Malaroda, 1946; Churcher, 1988), Angola (Telles Antunes, 1964; Lingham-Soliar, 1999) and Brazil (Price, 1957). These teeth have been attributed by the above authors to Globidens fraasi Dollo, 1913, G. aegyptiacus Zdansky, 1935, G. cf. alabamaensis Gilmore, 1912 and Globidens sp.

Globidens fraasi has lately been synonymised with Carinodens belgicus (see Schulp et al., 2004), and the genus Igdamanosaurus was erected for G. aegyptiacus (LinghamSoliar, 1991). On the one hand, the teeth from Morocco, Middle East, Angola and Brazil differ from those of Carinodens and Igdamanosaurus. On the other hand, teeth of Globidens alabamaensis and $G$. dakotensis differ from the Moroccan ones in having a spherical cross-section, a small symmetrical apical nubbin or point, faint sulci or none at all, and fairly smooth enamel (Russell, 1975, pls. 2-3, 'type 1'; Lingham-Soliar, 1999, pl. 5, fig. 7, 'type 1'). These species are restricted to the Campanian of North America; there is a single record from the Campanian of Europe (Dollo, 1924; Russell, 1975).

Reconstruction - A reconstruction of the dental tooth row of Globidens phosphaticus nov. sp. is here proposed in Fig. 2, based both on observations made on the large sample of Globidens teeth available from Morocco and on comparisons with other species of Globidens for which tooth morphology is known, i.e. the maxilla of the type of $G$. alabamaensis (USNM 6527; Gilmore, 1912), the premaxilla-maxilla of the type of $G$. dakotensis (FMNH PR 846; Russell, 1975) and an unpublished dentary from the Campanian of Kansas, referred to as Globidens sp. (FHSM VP-13828; courtesy of M. Everhart). The following observations can be made from these comparisons:

Firstly, in our large sample, six morphotypes have been recognised (see above). For parsimonious reasons, they are here interpreted as corresponding to different positions along the jaws of the same taxon rather than to belong to different species. Indeed, these morphotypes are associated continuously along the Maastrichtian series of the Ganntour Basin. In term of habitat partitioning, the coexistence of two species of the highly specialised genus Globidens in the same habitat all along the Maastrichtian seems unlikely. Moreover, no significant morphological differences have been found between small and large teeth of the same morphotypes. Those that have been observed (i.e., more clearly marked sulci and anastomosing ridges on larger specimens) are linked to size allometry. Finally, differences linked to sexual dimorphism are currently impossible to demonstrate.

Secondly, the maxilla of $G$. alabamaensis preserves ten teeth or alveoli but originally probably eleven or twelve teeth must have been present (Gilmore, 1912). The premaxillamaxilla of $G$. dakotensis bear fifteen teeth. The complete dentary of Globidens sp. is robust, dorsally concave as in Prognathodon. It bears fourteen teeth, the largest being the median ones, as usual in mosasaurs. There is no significant difference of dentition between the upper and lower jaws in any of these North American species of Globidens.

Thirdly, only four morphotypes have been recognised in both the premaxilla-maxilla of $G$. dakotensis and in the dentary of Globidens sp.; the dental tooth row of the maxilla of $G$. alabamaensis is too incomplete. Anterior teeth are broad, tall cones; anteromedian teeth broad cones of equal height and length; median teeth large and bulbous; posterior teeth bulbous and low. Four teeth are considered anterior, two anteromedian, five (FHSM VP-13828) to six (FMNH PR 846) median, and three posterior.

On the basis of these observations, it is hypothesised that: 1. About the same number of teeth (around 14) was present in Globidens phosphaticus nov. sp. as compared to the North American Globidens species. Its dental series is reconstructed on the basis of this tooth count. A total of thirteen teeth are figured (Fig. 2).

2. About the same number of anterior, median and posterior teeth with the same size proportions were present in Globidens phosphaticus nov. sp. as compared to the Globidens sp. from Kansas (FHSM VP-13828). The dorsal margin of the dentary of $G$. phosphaticus nov. sp. was probably concave (and the ventral margin convex) as in Globidens sp. and Prognathodon. This condition is retained by Globidensini but Carinodens and was probably linked to the robustness of the jaw.

3. The dentition of Globidens phosphaticus nov. sp. is interpreted as being more heterodont than those of the North American species of Globidens.

Discussion - Globidens phosphaticus nov. sp. is now known from all levels within the Maastrichtian phosphatic series of the Ben Guerir area (Ganntour Basin). Its stratigraphical range probably spans the entire Maastrichtian. So far, this taxon is 
unknown from the upper CIII level in the Oulad Abdoun Basin, but teeth probably assignable to it have been observed in the lower CIII level near Casbah Tadlah, southeast of the Oulad Abdoun Basin (0. Zelloum, pers. comm.). Globidens phosphaticus nov. sp. is currently on record from Africa, the Middle East and Brazil, so that its palaeobiogeographical distribution covers the southern margin of the Mediterranean Tethys around palaeolatitudes $20^{\circ} \mathrm{N}-20^{\circ} \mathrm{S}$.

Prognathodon Dollo, 1889

Type species - Prognathodon solvayi Dollo, 1889, lower Maastrichtian of southern Belgium (Lingham-Soliar \& Nolf, 1990); subsequently also recorded from the Maastrichtian of the Basque Country (Bardet et al., 1999).

Distribution - Prognathodon is a large mosasaurid represented by eight species found in the Campanian-Maastrichtian of Europe (Lingham-Soliar \& Nolf, 1990; Dortangs et al., 2002; Lindgren, 2004), the Middle East (Bardet et al., 2000; Christiansen \& Bonde, 2002), North America (Russell, 1967; Kass, 1999), and New Zealand (Welles \& Gregg, 1971; Wiffen, 1990).

\section{Prognathodon currii Christiansen \& Bonde, 2002}

Referred material - OCP.DEK/GE 349, 350, two median teeth from level C5 (Ben Guerir area, Ganntour Basin, Maastrichtian) (Fig. 3); 0CP.DEK/GE uncatalogued, five teeth from different levels at Ben Guerir (Ganntour Basin; 1 from level C6, 1 from C4, 2 from C3, and 1 from C2).

Description - Tooth crowns are very large and stout, higher than long, subconical and nearly straight along their height (Fig. 3). The basal cross-section is elliptical and the base of the crown is slightly swollen. The tooth enamel surface is unfacetted and smooth except for the upper third which exhibits crude anastomosing ridges. The enamel is about 0.5 $\mathrm{mm}$ thick, especially in the apical region, giving the teeth a dark colour. There are two well-developed, serrated carinae along the entire height of the crown.

Comparisons - These specimens are remarkable in having straight crowns, a character known exclusively in Prognathodon currii from the Upper Cretaceous phosphates of Negev (Christiansen \& Bonde, 2002), in Goronyosaurus nigeriensis (Swinton, 1930) from the Maastrichtian of Niger (Azzarolli et al., 1972; Soliar, 1988) and in Igdamanosaurus aegyptiacus (Zdansky, 1935) from the Maastrichtian of Egypt and Niger (Lingham-Soliar, 1991). Teeth from the Ben Guerir area differ from those of Goronyosaurus in having much larger and stouter crowns. The crowns of Igdamanosaurus are comparatively lower (height almost equalling length) than the Moroccan ones and bear crude anastomosing striations along their height. The Moroccan
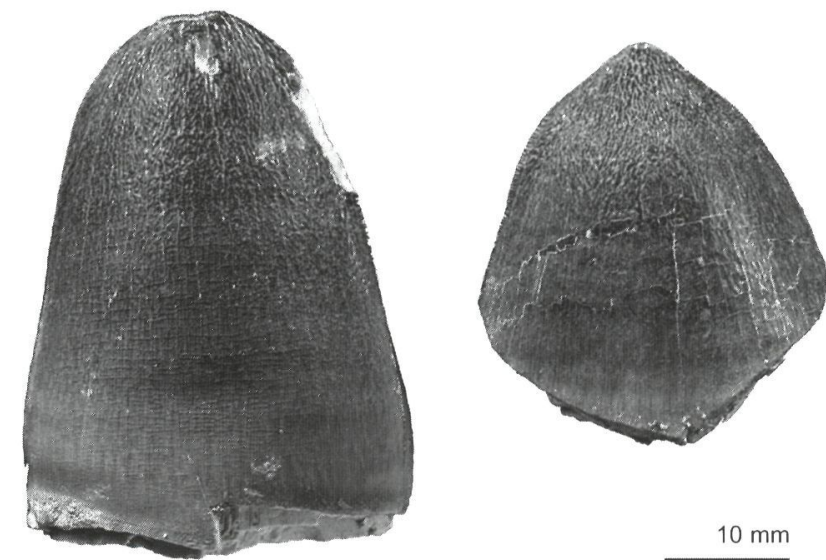

A

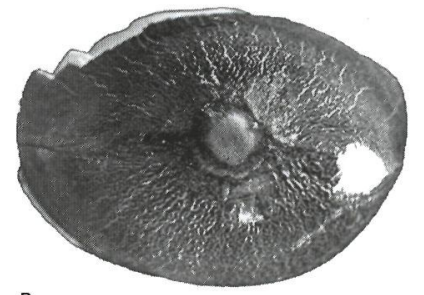

$B$

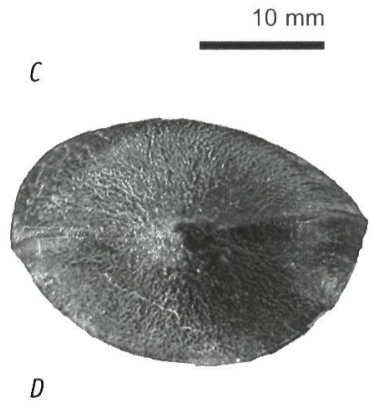

Fig. 3. Prognathodon currii. Maastrichtian phosphatic series of Ben Guerir area (Ganntour Basin, Morocco); A, B - OCP.DEK/GE 349, referred specimen, level C5, median tooth, in lateral or medial and occlusal view, respectively; C, D - OCP.DEK/GE 350, referred specimen, level C5, median tooth, in lateral or medial and occlusal view, respectively.

teeth conform well to the diagnosis given by Christiansen \& Bonde (2002) for those of $P$. currii, in being heavy with smooth enamel surfaces, nearly straight, conical with blunt apices, and in having occasionally serrated carinae.

The present specimens differ from teeth of other species of Prognathodon, which have posteriorly recurved crowns, and especially from the type species, $P$. solvayi Dollo, 1889 , which exhibits facets on both surfaces (Lingham-Soliar \& Nolf, 1990). Teeth of $P$. currii from Morocco more or less resemble those of P. giganteus Dollo, 1904 from the Maastrichtian of southern Belgium and the Middle East (Lingham-Soliar \& Nolf, 1990; Bardet et al., 2000) in having anastomosing ridges apically, but the latter has slender and posteriorly recurved teeth.

Discussion - Prognathodon currii has previously been recorded only from upper Campanian or lower Maastrichtian phosphates of Negev (Bardet et al., 2000; Christiansen \& Bonde, 2002). In Morocco, this species extends from the lower to upper Maastrichtian (levels C6 to C2) in the Ganntour Basin, but is unknown to date from the upper Maastrichtian (level CIII layer) in the Oulad Abdoun Basin.

Carinodens Thurmond, 1969

Type species - Bottosaurus belgicus Woodward, 1891, Maastrichtian of southern and NE Belgium and the Netherlands (Lingham-Soliar, 1999; Schulp et al., 2004). 
Distribution - Maastrichtian of Belgium, The Netherlands, Bulgaria (Tzankov, 1939) and Brazil (Price, 1957).

\section{Carinodens belgicus (Woodward, 1891)}

Referred material - MNHN Arambourg Collection (uncatalogued, now lost), an isolated tooth from the phosphates of Oued Meskoura, near El Borouj (Oulad Abdoun Basin), Maastrichtian (Fig. 4).

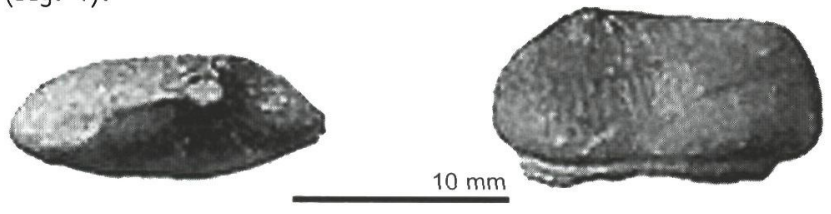

A B

Fig. 4. Carinodens belgicus. Maastrichtian phosphatic series of the El Borouj area (Oulad Abdoun Basin, Morocco). MNHN Arambourg Collection (uncatalogued), referred specimen (now lost), posteriormost tooth. $A, B$ - occlusal and lateral or medial views, respectively (modified from Arambourg, 1952, pl. 60, fig. 3).

Description - Arambourg's (1952, pl. 60, fig. 3) illustration shows the crown to be very low (approximately 2.5 times longer than high) and strongly laterally compressed and swollen at the base. In lateral view, it is subrectangular. It bears a worn, posteriorly located, apical nubbin, and there are two carinae. Enamel ornament shows coarse striae.

Comparisons - This tooth, described as Globidens aegyptiacus by Arambourg (1952), is perhaps better referred to Carinodens belgicus (Bardet et al., 2004b). It matches previous descriptions of this species well, in having low, swollen, laterally compressed, bicarinate crowns with a large apical nubbin (Dollo, 1913; Kuypers et al., 1998; Lingham-Soliar, 1999; Schulp et al., 2004).

In comparison to teeth preserved in the type specimen of Carinodens belgicus (IRScNB R43), the subrectangular shape of the Moroccan tooth would suggest a posterior position in the jaw. Moreover, the posteriorly located apical nubbin matches that seen in the last tooth of the dentary, which is the twelfth (Schulp et al., 2004).

Discussion - At present, this specimen cannot be traced in the Arambourg Collection (MNHN, Paris), and there are no subsequent records of teeth of this species from Morocco. Although represented by only few isolated remains, Carinodens belgicus has a wide palaeobiogeographical distribution (Maastrichtian of Europe, Brazil and Morocco; Schulp et al., 2004).

\section{Acknowledgements}

This work has benefited from the collaboration ("Tripartite Convention') of the Direction de la Géologie of the Ministère de l'Energie et des Mines and of the Office Cherrifien des
Phosphates in the Kingdom of Morocco. We are grateful to all staff members at the Ben Guerir OCP mining centre, in particular to M. Miftah, for hospitality and logistic support and to M. Sadiqui and L. Tabit of the Ministère de l'Energie et des Mines (Rabat) for providing administrative facilities and permits. Many thanks to H. Cappetta (CNRS, Montpellier), S. Adnet (Montpellier) and A. Ben Abdallah (Ministère de l'Energie et des Mines, Rabat) for their help in collecting mosasaur material and to D. Serrette, P. Loubry and H. Lavina (CNRS, MNHN, Paris) for preparation of illustrations. We also thank P. Godefroit (IRScNB, Bruxelles), J.W.M. Jagt and A.S. Schulp (Natuurhistorisch Museum Maastricht) for access to collections in their care and for providing useful data. This research was partially supported by funds from the National Geographic Society (Grant \#6627-99).

\section{References}

Arambourg, C., 1952. Les vertébrés fossiles des gisements de phosphates (Maroc-Algérie-Tunisie). Notes et Mémoires du Service géologique du Maroc 92: 1-372.

Arambourg, C., Dubertret, L., Signeux, J. \& Sornay, J., 1959. Contributions à la stratigraphie et à la paléontologie du Crétacé et du Nummulitique de la marge NW de la Péninsule arabique. Notes et Mémoires sur le Moyen-0rient 7: 193-251.

Avnimelech, M., 1949. On vertebrate remains in Senonian phosphate beds in Transjordan. Eclogae geologicae Helvetiae 42: 486-490.

Azzarolli, A., Claudio, G. de, Ficarelli, G. \& Torres, D., 1972. An aberrant mosasaur from the Upper Cretaceous of North Western Nigeria. Accademia nazionale dei Lincei, Classe di Scienze fisiche, matematiche e naturali, Rendiconti 52: 53-56.

Bardet, N. \& Pereda Suberbiola, X., 2002. Marine reptiles from the Late Cretaceous phosphates of Jordan: palaeobiogeographical implications. Geodiversitas 24: 831-839.

Bardet, N., Corral, J.C. \& Pereda Suberbiola, X., 1999. Marine reptiles from the uppermost Cretaceous of the Laño quarry (Iberian Peninsula). Estudios del Museo de Ciencias naturales de Alava, numero especial 14: 373-380.

Bardet, N., Cappetta, H., Pereda Suberbiola, X., Mouty, M., Al Maleh, A.K., Ahmad, A.M., Khrata, O. \& Gannoum, N., 2000. The marine vertebrate faunas from the Late Cretaceous phosphates of Syria. Geological Magazine 137: 269-290.

Bardet, N., Pereda Suberbiola, X., Iarochène, M., Bouyahyaoui, F., Bouya, B. \& Amaghzaz, M., 2004a. Mosasaurus beaugei Arambourg, 1952 (Squamata, Mosasauridae) from the Late Cretaceous phosphates of Morocco. Geobios 37: 315-324.

Bardet, N., Pereda Suberbiola, X., Iarochène, M., Bouya, B. \& Amaghzaz, M., 2004b. Mosasaurids from the Maastrichtian phosphates of Morocco. In: Schulp, A.S. \& Jagt, J.W.M. (eds): First Mosasaur Meeting, Abstract book and field guide (Natuurhistorisch Museum Maastricht, Maastricht): 13-14.

Bardet, N., Pereda Suberbiola, X., Iarochène, M., Bouya, B. \& Amaghzaz, M., 2005. A new species of Halisaurus from the Late Cretaceous phosphates of Morocco, and the phylogenetical relationships of the Halisaurinae (Squamata: Mosasauridae). Zoological Journal of the Linnean Society 143: 447-472. 
Bourdon, E., Bouya, B. \& Iarochène, M., 2005. Earliest African neornithine bird: a new species of Prophaethontidae (Aves) from the Paleocene of Morocco. Journal of Vertebrate Paleontology 25(1): 157-170.

Cappetta, H., 1987. Mesozoic and Cenozoic Elasmobranchii, Chondrichthyes. In: Schultze, H.-P. (ed.): Handbook of Paleoichthyology, Vol. 3b. G. Fischer (Stuttgart, New York): $193 \mathrm{pp}$.

Cavin, L., Bardet, N., Cappetta, H., Gheerbrant, E., Iarochène, S.M. \& Sudre, J., 2000. A new Palaeocene albulid (Teleostei, Elopomorpha) from the Ouled Abdoun phosphatic Basin, Morocco. Geological Magazine 137: 583-591.

Christiansen, P. \& Bonde, N., 2002. A new species of gigantic mosasaur from the Late Cretaceous of Israel. Journal of Vertebrate Paleontology 22: 629-644.

Churcher, C.S., 1988. Marine vertebrates from the Duwi phosphorites, Dakhleh Oasis, Western Desert of Egypt. Journal of Vertebrate Paleontology 8 (Suppl. to 3$): 11 \mathrm{~A}$.

DeBraga, M. \& Carroll, R.L., 1993. The origin of mosasaurs as a model of macroevolutionary patterns and processes. In: Hecht, M.K. et al. (eds): Evolutionary Biology 27: 245-322.

Dollo, L., 1889. Première note sur les mosasauriens de Mesvin. Bulletin de la Société belge de Géologie, de Paléontologie et d'Hydrologie 3: 271-304.

Dollo, L., 1904. Les mosasauriens de la Belgique. Bulletin de la Société belge de Géologie, de Paléontologie et d'Hydrologie 18: 207-216.

Dollo, L., 1913. Globidens fraasi, mosasaurien mylodonte nouveau du Maestrichtien (Crétacé supérieur) du Limbourg, et l'éthologie de la nutrition chez les mosasauriens. Archives de Biologie 28: 609-626.

Dollo, L., 1924. Globidens alabamaensis, mosasaurien mylodonte américain retrouvé dans la craie d'Obourg (Sénonien supérieur) du Hainaut et les mosasauriens de la Belgique en général. Archives de Biologie 34: 167-213.

Dortangs, R.W., Schulp, A.S., Mulder, E.W.A., Jagt, J.W.M., Peeters, H.H.G. \& de Graaf, D.Th., 2002. A large new mosasaur from the Upper Cretaceous of the Netherlands. Netherlands Journal of Geosciences 81: 1-8.

Gervais, P., 1853. Observations relatives aux reptiles fossiles de France. Comptes Rendus de l'Académie des Sciences de Paris 36: 374-377, 470-474.

Gheerbrant, E., Sudre, J., Cappetta, H., Mourer-Chauviré, C., Bourdon, E., Iarochène, M., Amaghzaz, M., \& Bouya, B., 2003. Les localités à Mammifères des carrières de Grand Daoui, Bassin des Ouled Abdoun, Maroc, Yprésien: premier état des lieux. Bulletin de la Société géologique de France 174: 279-293.

Gilmore, C.W., 1912. A new mosasauroid reptile from the Cretaceous of Alabama. Proceedings of the United States National Museum 41: 479-484.

Herbig, H.G., 1986. Lithostratigraphisch-fazielle Untersuchungen im marinen Alttertiär südlich des zentralen Hohen-Atlas (Marokko). Berliner geowissenschaftliche Abhandlungen 66: 343-380.

Hua, S. \& Jouve, S., 2004. A primitive marine gavialoid from the Paleocene of Morocco. Journal of Vertebrate Paleontology 24: 341-350.

Jouve, S., 2004. Etude des faunes de Crocodyliformes fini Crétacé-Paléogène du Bassin des Oulad Abdoun (Maroc) et comparaison avec les faunes africaines contemporaines: systématique, phylogénie et paléobiogéographie. $\mathrm{PhD}$ thesis (Muséum national d'Histoire naturelle, Paris), $651 \mathrm{pp}$.

Jouve S., Bouya, B. \& Amaghzaz, M., 2005. A short-snouted dyrosaurid (Crocodyliformes, Mesoeucrocodylia) from the Palaeocene of Morocco. Palaeontology 48: 359-369.
Kass, M.S., 1999. Prognathodon stadtmani: (Mosasauridae) A new species from the Mancos Shale (Lower Campanian) of Western Colorado. Utah Geological Survey, Miscellaneous Publications 99: 275-294.

Kuypers, M.M.M., Jagt, J.W.M., Peeters, H.H.G., de Graaf, D.Th., Dortangs, R.W., Deckers, M.J.M., Eysermans, D., Janssen, M.J. \& Arpot, L., 1998. Laat-kretaceische mosasauriërs uit Luik-Limburg: nieuwe vondsten leiden tot nieuwe inzichten. Publicaties van het Natuurhistorisch Genootschap in Limburg 41: 5-47.

Leonardi, P. \& Malaroda, R., 1946. Prima segnalazione di un mosasauro del genere Globidens nel Cretaceo del'Egytto. Acta Pontificia Accademia scientorum 10: 183-188.

Lindgren, J. \& Siverson, M., 2002. Tylosaurus ivoensis: a giant mosasaur from the early Campanian of Sweden. Transactions of the Royal Society of Edinburgh, Earth Sciences, 93: 73-93.

Lindgren, J., 2004. Stratigraphical distribution of Campanian and Maastrichtian mosasaurs in Sweden - evidence of an intercontinental marine extinction event? GFF 126: 221-229.

Lingham-Soliar, T., 1991. Mosasaurs from the Upper Cretaceous of Niger. Palaeontology 34: 653-670.

Lingham-Soliar, T., 1999. The durophagous mosasaurs (Lepidosauromorpha, Squamata) Globidens and Carinodens from the Upper Cretaceous of Belgium and The Netherlands. Paleontological Journal 33 (Suppl.): s638-s647.

Lingham-Soliar, T. \& Nolf, D., 1990. The mosasaur Prognathodon (Reptilia, Mosasauridae) from the Upper Cretaceous of Belgium. Bulletin de l'Institut royal des Sciences naturelles de Belgique, Sciences de la Terre 59 (1989): 137-190.

Lucas, J. \& Prévôt-Lucas, L., 1996. Tethyan phosphates and bioproductites. In: Nairn, A.E.M. et al. (eds): The Ocean Basins and Margins, the Tethys 0cean. Plenum Press (New York): 367-391.

Mustafa, H. \& Zalmout, I., 2001. On the dentition of Mosasauridae (marine reptiles) from the Late Cretaceous (Early Maastrichtien) of the Jordanian Phosphate. Dirasat, Pure Science 28: 56-62.

Office Cherifien des Phosphates, 1989. The phosphates basins of Morocco. In: Northolt, A.J.G., Sheldon, R.P. \& Davidson, D.F. (eds): Phosphates deposits of the world, Vol. 2 - Phosphate rock resources. Cambridge University Press (Cambridge): 301-311.

Oppel, M., 1811. Die Ordnungen, Familien und Gattungen der Reptilien als Prodrom einer Naturgeschichte derselben. Joseph Lindauer (München): $87 \mathrm{pp.}$

Pereda Suberbiola, X., Bardet, N., Jouve, S., Iarochène, M., Bouya, B. \& Amaghzaz, M., 2003. A new azhdarchid pterosaur from the Late Cretaceous phosphates of Morocco. In: Buffetaut E. \& Mazin J.-M. (eds), Evolution and Palaeobiology of Pterosaurs. Geological Society of London, Special Publication 217: 79-90.

Pereda Suberbiola, X., Bardet, N., Iarochène, M., Bouya, B. \& Amaghzaz, M., 2004. The first record of a sauropod dinosaur from the Late Cretaceous phosphates of Morocco. Journal of African Earth Sciences 40: 81-88.

Price, L.I., 1957. A presença de Globidens no Cretácico superior do Brasil. Divisão de Geologia e Mineralogia, Boletim 169: 1-24.

Raab, M., 1963. Fossil fish and reptiles from Late Campanian phosphatic deposits of the Negev Region of Israel. Israel Journal of Earth Sciences 12: 26-40.

Russell, D.A., 1967. Systematics and morphology of American mosasaurs. Bulletin of the Peabody Museum of Natural History, Yale University 23: 1-241. 
Russell, D.A., 1975. A new species of Globidens from South Dakota, and a review of Globidentine mosasaurs. Fieldiana, Geology 33: 235-256.

Salvan, H.M., 1986. Paléogéographie générale. In: Géologie des gîtes minéraux marocains, 3: Phosphates. Notes et Mémoires du Service géologique du Maroc 276: 139-152.

Schulp, A.S., Jagt, J.W.M. \& Fonken, F., 2004. New material of the mosasaur Carinodens belgicus from the Upper Cretaceous of The Netherlands. Journal of Vertebrate Paleontology 24: 744-747.

Soliar, T., 1988. The mosasaur Goronyosaurus from the Upper Cretaceous of Sokoto State, Nigeria. Palaeontology 31: 747-762.

Swinton, W.E., 1930. On fossil Reptilia from the Sokoto Province. Bulletin of the Geological Survey of Nigeria 13: 1-56.

Telles Antunes, M., 1964. O Neocretácico e o Cenozóico do litoral de Angola. Junta de Investigações do Ultramar (Lisboa): $255 \mathrm{pp}$.

Thurmond, J.T., 1969. New name for the mosasaur Compressidens Dollo, 1924. Journal of Paleontology 43: 1298.

Tzankov, V., 1939. Note sur la présence des reptiles fossiles du Crétacé supérieur de la Bulgarie du Nord. Geologica Balkanica 3: 13-20.

Welles, S.P. \& Gregg, D.R., 1971. Late Cretaceous marine reptiles of New Zealand. Records of the Canterbury Museum 9: 1-111.

Wiffen, J., 1990. New mosasaurs (Reptilia; Family Mosasauridae) from the Upper Cretaceous of North Island, New Zealand. New Zealand Journal of Geology and Geophysics 33: 67-85.

Woodward, A.S., 1891. Note on a tooth of an extinct Alligator (Bottosaurus belgicus, sp. nov.) from the Lower Danian of Ciply, Belgium. Geological Magazine (3)8: 114-115.

Zdansky, 0. 1935. The occurrence of mosasaurs in Egypt and in Africa in general. Bulletin de l'Institut d'Egypte 17: 83-94. 